\title{
Home Range, Diet, and Activity Patterns of Common Marmosets (Callithrix jacchus) in Very Small and Isolated Fragments of the Atlantic Forest of Northeastern Brazil
}

\author{
Herbert Leonardo Nascimento Pinheiro ${ }^{1}$ and Antonio Rossano Mendes Pontes ${ }^{1,2}$ \\ ${ }^{1}$ Programa de Pós-graduação em Biologia Animal (PPGBA), Departamento de Zoologia, \\ Universidade Federal de Pernambuco (UFPE), Rua Prof. Moraes Rego 1235, Cidade Universitária, 50.740-620 Recife, PE, Brazil \\ ${ }^{2}$ Instituto Nacional de Pesquisas da Amazônia (INPA), Núcleo de Pesquisas de Roraima (NPRR), \\ Rua Coronel Pinto 315, Centro, 69.301-150 Boa Vista, RR, Brazil \\ Correspondence should be addressed to Herbert Leonardo Nascimento Pinheiro; ferrugembio@gmail.com
}

Received 28 April 2015; Revised 7 July 2015; Accepted 22 July 2015

Academic Editor: Daniel I. Rubenstein

Copyright (C) 2015 H. L. N. Pinheiro and A. R. Mendes Pontes. This is an open access article distributed under the Creative Commons Attribution License, which permits unrestricted use, distribution, and reproduction in any medium, provided the original work is properly cited.

\begin{abstract}
We evaluate the impact of very small and isolated forest fragments on the common marmosets home range, diet, and activity patterns, in the northeastern Atlantic Forest of Brazil. Three groups were studied in three forest fragments, from January to October 2010, totaling 360 hours of observations and 1,080 field-hours. Systematic observations were recorded using Instantaneous Scan Sampling, and a checklist of the items exploited was built through ad libitum observations. We recorded location of the groups and calculated home range. We recorded 11,639 scans and 236 ad libitum feeding records. 83.4\% $(n=10)$ of food items were plant species, the only animal protein was from insects $(n=2 ; 16.6 \%)$, and the diet was based almost exclusively on gums. Mean home range was 5.5 ha, mean daily path length was 1,167 meters, and no differences were detected between seasons. Resting dominated their activity budget and varied between seasons. Common marmosets survived in this environment through a remarkable increase in their exploitation of tree gums (up to $98 \%$ of their feeding bouts) to compensate for the lack of food, in home ranges slightly larger than in the literature. Thus, they travelled and foraged less than expected and rested more since food was easily obtained.
\end{abstract}

\section{Introduction}

Common marmosets (Callithrix jacchus) are endemic to one of the most imperiled sectors of the Atlantic Forest, the Pernambuco Endemism Center ([1]; hereafter PEC), a hotspot's hotspot, or an even biodiversity richer area within a hotspot, in northeastern Brazil [2-4]. Current forest cover in the PEC is less than $2 \%$ of the original area [5]; more than $70 \%$ of the remaining forest fragments are less than 10 hectares in area (Mendes Pontes, in prep.), highly modified in botanical composition, and isolated by sugar-cane plantations and have reduced food availability [6-8].

Consequently, most mammalian species have been extirpated from the PEC $[9,10]$. Common marmosets, however, are a highly adaptable species that thrives in secondary forests, forest borders, and even suburban areas, such as orchards and backyards [11-13]. Consequently, they are one of the few that have survived in this environment.

Despite common marmosets being considered exudativorous-insectivorous [14], they are a highly adaptable species. They range from evergreen Atlantic Forest to dryscrub Caatinga. Depending on the habitat and the seasonality of its resources, they can focus more on fruit, gum (exudate), or animal matter $[13,15,16]$. This appears to be a function of the availability of fruit, their preferred food source [14-18].

Gummivory is a major dietary trait for a variety of primate species, including prosimians, some African cercopithecines, and especially callitrichids, the latter exploiting it from a wide variety of tree species and all year round [19]. Although gum is difficult to obtain, limited in quantity, and difficult to digest [20], high rates of gum feeding (up to $87 \%$ of feeding time) have been recorded for Brazilian Atlantic Forest 


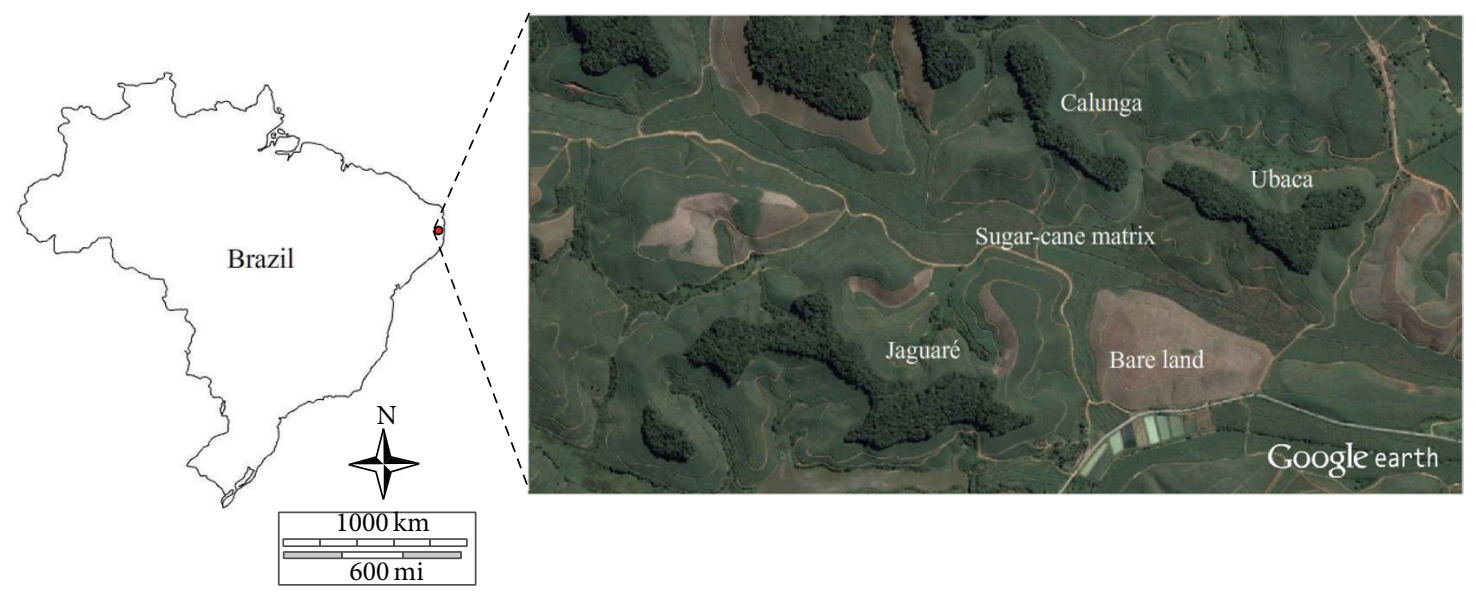

Figure 1: Location of the study site at Usina Trapiche, in the Atlantic Forest of Northeast Brazil, showing the studied fragments: (a) Jaguaré, (b) Ubaca, and (c) Calunga. Images obtained from Google Earth.

callitrichids, although fruit can be the most exploited food source [21-26].

In common marmosets the activity budget appears to be dominated by foraging and feeding, with these activities summing up to $55 \%$ of the diurnal time budget, although it varies with habitat type, distribution, abundance, seasonality of the feeding resources, and time of the day [21, 23, 27]. Common marmosets typically have activity patterns with two feeding peaks, one in the early morning and another one at the end of the afternoon, and a peak of resting in the middle of the day $[12,15,18,28,29]$. In both the Atlantic Forest of northeastern Brazil and the dry-scrub Caatinga forest, they often invest most of their time in foraging, especially in the dry season, and up to $50 \%$ of their time in foraging and feeding $[15,28,30]$.

Home range size can be very variable in Brazilian Atlantic Forest callitrichids, ranging from 10 to 38 ha [22-26, 31, 32], and appears to be smaller in the xeromorphic semideciduous woodlands Cerrado and Cerradão [33, 34]. Common marmosets home range sizes are considerably smaller, ranging from only 1.2 to 5.2 ha $[12,15,17,28,35-38]$, and can vary according to habitat quality and degree of human impact, with larger home ranges being recorded in areas subjected to more severe human degradation. Home range size may also vary with the availability of food resources, with larger areas being recorded during food scarcity, when animals must travel further to find food [12, 15, 38, 39].

Daily paths travelled by callitrichids in the Brazilian Atlantic Forest have a mean of 1,000 m, varying between 830 and $1,498 \mathrm{~m}[22-24,31,32,40]$. In the common marmosets in the northeastern Atlantic Forest home range varies from 912 to $1,300 \mathrm{~m}$ and appears to be determined by seasonal variation in fruiting, sleeping locations, and plant cover $[12,15,37,39]$.

In this study we evaluated the impact of living in very small, isolated, and highly impacted forest fragments on the common marmosets home range, diet, and activity patterns. We expected to find the studied groups of common marmosets using significantly larger home ranges, investing comparatively more time in foraging, especially in the dry season, and having a highly simplified diet, with comparatively few

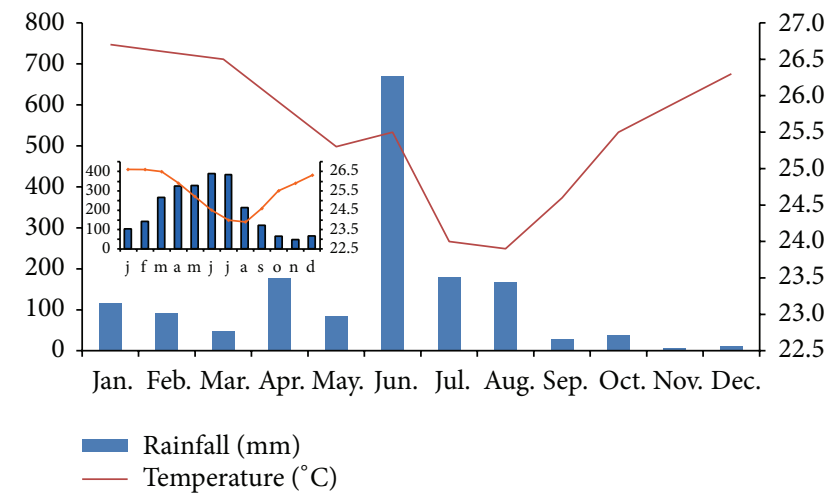

FIgURE 2: Temperature and rainfall in the study area at Usina Trapiche, in the Atlantic Forest of Northeast Brazil, during the study year 2010 (in comparison with the previous year 2009).

food items exploited, since the areas are highly impacted and the forest fragments are very small.

\section{Methods}

2.1. Study Area. The study was conducted in three forest fragments at Usina Trapiche, Sirinhaém, state of Pernambuco, Northeast Brazil, at PEC: Jaguaré $\left(8^{\circ} 32^{\prime} 52.3^{\prime \prime} \mathrm{S}, 35^{\circ} 11^{\prime} 44.2^{\prime \prime} \mathrm{W}\right.$; $10 \mathrm{ha})$, Ubaca $\left(8^{\circ} 32^{\prime} 35.37^{\prime \prime} \mathrm{S}, 35^{\circ} 11^{\prime} 04.63^{\prime \prime} \mathrm{W} ; 8.2 \mathrm{ha}\right)$, and Calunga $\left(8^{\circ} 32^{\prime} 24.23^{\prime \prime} \mathrm{S}, 35^{\circ} 11^{\prime} 33.79^{\prime \prime} \mathrm{W}\right.$; 7.1 ha) (Figure 1), all of which are formed by submontane dense tropical rainforests preserved on steep hilltops that were not suitable for agriculture [41].

Sirinhaém has a pseudotropical to tropical hot-humid weather, with the rainy season occurring from May to September, when a maximum of 2,000 mm may be recorded in the peak of the rainy season around June [42]. The study year in Sirinhaém, nevertheless, was highly atypical, with substantial rainfall occurring in one month (Figure 2).

2.2. Studied Groups. Three social groups comprised of eight to 13 individuals were studied (one in each study site). Their 
TABLE 1: Group composition of the three studied groups of common marmosets (Callithrix jacchus) in three forest fragments at Usina Trapiche, Northeast Brazil.

\begin{tabular}{|c|c|c|c|c|c|c|c|c|c|c|c|c|c|}
\hline \multirow{2}{*}{ Group } & \multicolumn{3}{|c|}{ Adult } & \multicolumn{3}{|c|}{ Subadult } & \multicolumn{3}{|c|}{ Juvenile } & \multicolumn{3}{|c|}{ Infant } & \multirow{2}{*}{ Total } \\
\hline & Male & Female & $?$ & Male & Female & $?$ & Male & Female & $?$ & Male & Female & $?$ & \\
\hline Jaguaré & 5 & 3 & & & & & 1 & & & & & $2^{*}$ & $9\left(11^{* *}\right)$ \\
\hline Ubaca & 1 & 1 & & 2 & 2 & & 2 & & & & & $1^{*}$ & $8\left(9^{* *}\right)$ \\
\hline Calunga & 5 & 4 & & 1 & 1 & & & & & 2 & & & 13 \\
\hline
\end{tabular}

${ }^{*}$ Born to the group later in the study; ${ }^{* *}$ number of individuals at the end of the study.

age-sex composition was determined according to Yamamoto [43]: infant $(<5$ months: those individuals who are carried all the time by the family members); juvenile (5-10 months: young individuals who are still carried by family members but start soliciting grooming and grooming others and also socially play with other siblings and parents); subadult (1015 months: young individuals who are slenderer than adults but master most of the adult behavioral repertoire), and adult (>15 months).

When research began in January 2010 Jaguaré had nine individuals (in June 2010 twins were born), and there were two other adjacent groups in this fragment; Ubaca had eight individuals (in May 2010 one infant was born), and the group shared this fragment with another adjacent group; Calunga had 13 individuals and no other groups were found in this fragment (Table 1).

2.3. Checklist of Plant Species and Vegetation Structure. In each of the three studied forest fragments we sampled the vegetation in one $10 \times 100 \mathrm{~m}$ plot $(0.1 \mathrm{ha})$ situated within the group's home range, in which all trees $\geq 10 \mathrm{~cm}$ of diameter at breast height (DBA) were marked, identified, and counted [44]. This allowed us to calculate absolute density (number of individuals of a species per ha), relative density (density of one species as a percent of total plant density), relative dominance (dominance of one species as a percent of total plant dominance), Importance Value Index (IVI), which is the sum of relative frequency, relative density, and relative dominance, and Cover Value Index (CVI), which is the sum of relative density with relative dominance. We used FITOPAC software v.2.0 [45].

2.4. Observational Protocol. The study groups were already habituated to the constant human presence within and around the fragments, which were very small, close to houses, and crossed by paths regularly used by local people to collect forest resources. Therefore, after a maximum of five days the groups were all habituated to the presence of the observer. Each study group was followed from the time it left the sleeping tree in the morning $(\sim 05: 00 \mathrm{~h})$ to the time it entered the next sleeping tree in the afternoon $(\sim 17: 00 \mathrm{~h})$. Each group was studied during three consecutive days per month from January to October 2010, totaling 360 hours of observations (180 hours in the dry season and 180 hours in the wet season), or a total sampling effort of 1,080 hours. Due to field constraints no data from forest fragment Ubaca is available (only for the dry season).

Behavioral activities of each sighted individual in each of the studied groups were systematically recorded using
Instantaneous Scan Sampling [46], with sampling units of $1 \mathrm{~min}$. duration and $15 \mathrm{~min}$. intervals, the latter to allow the observer to effectively move through the steep hilltops of the three studied fragments. Instantaneous scans were taken as a camera flash and conducted from left to right or vice versa depending on the position of the observer. Whenever some individuals were not visible within the $1 \mathrm{~min}$. sampling units (e.g., moved out of sight while the others were feeding), the observational period was extended until all animals were sighted (up to $5 \mathrm{~min}$.). In order to build a checklist of the items exploited in the diet of the individuals, we used ad libitum observations [46] and recorded whenever the animals were feeding.

We recorded the location of the studied groups using a Global Positioning System (GPS Garmin Map 60CSX) every 15 minutes following a scan. Recorded points were then collated for each group and group home range was estimated using Calhome software (California HOME Range, US Forest Service, Pacific Southwest Research Station) [47].

A total of 11,639 records were obtained with scan sampling (Jaguaré, $n=4,375$; Ubaca, $n=3,703$; Calunga $n=$ 3,561). An additional 236 ad libitum feeding records were also obtained (Jaguaré, $n=52$; Ubaca, $n=87$; Calunga, $n=97)$. These were used exclusively for constructing the exploited food items checklist.

The studied behaviours were classified as follows:

(1) Foraging: individuals being actively searching for vegetal or animal foods, walking slowly, and scanning the environment, or turning over leaves and debris for prey.

(2) Feeding: taking to the mouth and chewing and/or swallowing any food item.

(3) Locomotion: moving through the forest without any apparent foraging behavior.

(4) Resting: when animals were motionless.

(5) Social: any interaction with members of the same or other neighbouring groups (adapted from Alonso and Langguth [15]).

Samples of reproductive and/or vegetative parts of the plant species exploited as food sources by the marmosets were collected, whenever possible, identified, and deposited in the Herbarium of the Universidade Federal de Pernambuco. Samples of the prey species were also collected whenever possible and deposited at the Zoological Collections of the same university. 
2.5. Data Analysis. In order to test if there were any statistically significant differences in the exploitation of the food items by the studied groups in the different seasons we used a Pearson's chi-square test with Yates' continuity correction. We tested the exploitation of the different food items in each group separately with an exact binomial test. Since the number of feeding records of fruit, flower, and prey was low we lumped them under the category "other." We used a Spearman correlation to test for statistically significant correlations of the number of gum feeding records on the two exploited tree species, Tapirira guianensis and Parkia pendula, with the following structural variables: absolute density, relative density, relative dominance, Importance Value Index (IVI), and Cover Value Index (CVI).

We used a Kruskal-Wallis test to check for statistically significant differences in home range sizes among the three groups and, for those groups that had differences, we further used a Mann-Whitney test to check differences between two groups.

We used a Mann-Whitney test to check if any statistically significant difference existed in the size of the home range of the studied groups in the different seasons and a Spearman correlation test to check if there was any correlation between the size of their home range and the size of the forest fragment.

We used an ANOVA to test if there was any statistically significant difference in the daily path length of the studied groups. If a significant difference was found, we used the Tukey post hoc test to test if there was any statistically significant difference in the total daily path length of the studied groups in the different seasons, as well as in the total daily path length of each group separately in the different seasons.

For each group we tested if there was any statistically significant difference in the total number of behavioural records in the different seasons with a Pearson's chi-square test with Yates' continuity correction. In order to test if there was any statistically significant difference in each of the frequencies of each of the studied behaviours in the different seasons, we used an exact binomial test. All statistical tests were performed using the software R ( $\mathrm{R}$ Core Development Team) version 3.2.

\section{Results}

3.1. Checklist of Plant Species and Vegetation Structure. A total of 42 plant species (of 19 families) were recorded in the three forest fragments, of which 24 (13 families) were in Jaguaré (10 ha), 16 (7 families) in Ubaca (8.2 ha), and 22 (12 families) in Calunga (7.1 ha) (Table 2). The highest diversity index was registered in Jaguaré (Shannon Index: 3.01), as was also the highest basal area ( $\left.41 \mathrm{~m}^{2} / \mathrm{ha}\right)$, whereas the highest equitability index was in Calunga (equitability index: 0.95) (Table 2).

In Jaguaré the species with the highest Importance Value Index (IVI = 24.4) and Cover Value Index (CVI = 20.23) was Apuleia leiocarpa (Caesalpiniaceae) and in Ubaca $(\mathrm{IVI}=64.61 ; \mathrm{CVI}=58.36)$ and Calunga $(\mathrm{IVI}=42.5$; CVI = 37.95) (Table 2) was Parkia pendula (Mimosaceae). In each fragment a different species was most abundant:

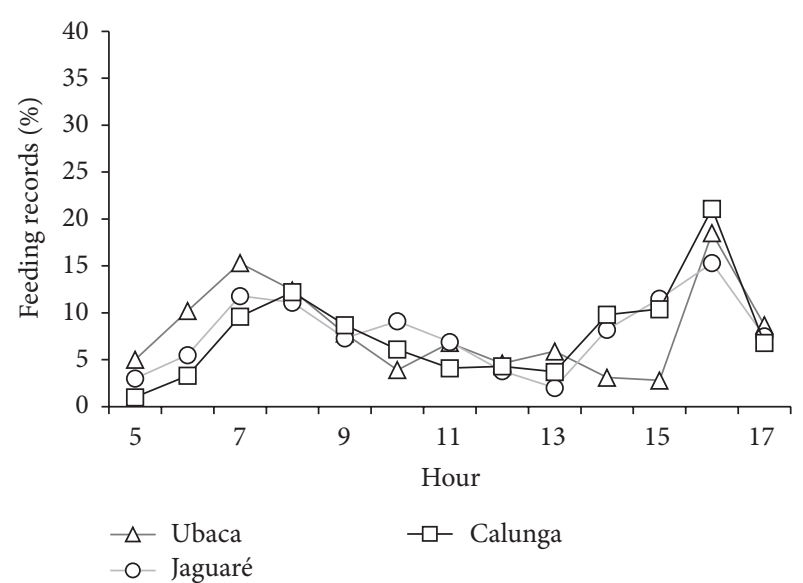

FIGURE 3: Distribution of the feeding records of the study groups along the day at Usina Trapiche, in the Atlantic Forest of Northeast Brazil.

in Jaguaré it was Balizia pedicellaris, (Papilionoideae) with 50 ind./ha, in Ubaca Parkia pendula (70 ind./ha) and Thyrsodium spruceanum (Anacardiaceae) (70 ind./ha), and in Calunga Tapirira guianensis (50 ind./ha) (Table 2).

3.2. Diet. During this study $83.4 \%(n=10)$ of the food items that we recorded the common marmosets exploiting were plant species, of which $70 \%(n=7)$ were fruit, $20 \%(n=2)$ were gum, and $10 \%(n=1)$ were flowers (Table 3$)$. Only one species was introduced (Syzygium jambolanum, Myrtaceae). The only animal protein exploited came from insects $(n=2$; $16.6 \%$ ) (Table 3). Feeding bouts had two marked peaks, which occurred between 07:00 and 08:00 h and around 16:00 h. The lowest feeding bout rates for all groups were recorded between 13:00 and 15:00 h (Figure 3).

The diet of the studied groups in the three forest fragments was very similar, being based almost exclusively on gums. These were obtained solely from two tree species Tapirira guianensis (Anacardiaceae), whence they obtained it by gouging the trunk to cause a flow of exudate which they then licked, and Parkia pendula (Fabaceae), where they licked the exudate that flowed spontaneously from mature seed pods.

At Jaguare the marmosets fed on gum from 12 Tapirira guianensis and 10 Parkia pendula in 97\% $(n=420)$ of the feeding bouts, at Ubaca from 17 Tapirira guianensis and 10 Parkia pendula in $97.6 \%(n=440)$ of the feeding bouts, and at Calunga from 18 Tapirira guianensis and seven Parkia pendula in $98.3 \%$ ( $n=860)$ of the feeding bouts. They consumed fruits at Jaguaré $(0.7 \% n=3)$, at Ubaca $(1.6 \% n=7)$, and at Calunga $(1.7 \% n=15)$, animal prey at Jaguaré $(2.3 \% n=10)$ and Ubaca $(0.4 \% n=2)$, and flower in Ubaca $(0.4 \% n=2)$.

There was a statistically significant difference in the number of feeding bouts in the different seasons in Jaguaré $\left(X^{2}=23.31, \mathrm{df}=1, p<0.0001\right)$ and Ubaca $\left(X^{2}=10.67, \mathrm{df}\right.$ $=1, p=0.001)$, with more feeding bouts in the rainy season, but no difference was detected in Calunga $\left(X^{2}=0.167, \mathrm{df}=1\right.$, $p=0.682$ ). Gum was significantly more exploited in the 
TABLE 2: Checklist of the plant species and vegetation structure of the studied forest fragments at Usina Trapiche, Northeast Brazil.

\begin{tabular}{|c|c|c|c|c|c|}
\hline \multicolumn{6}{|l|}{ Forest fragment } \\
\hline \multicolumn{6}{|l|}{ Jaguaré } \\
\hline \multicolumn{6}{|l|}{ Total fragment area: 10 ha } \\
\hline \multicolumn{6}{|c|}{ Home range of the studied common marmoset group: 5.8 ha } \\
\hline \multicolumn{6}{|c|}{ Number of plant species: 24 (13 families) } \\
\hline \multicolumn{6}{|l|}{ Shannon Index: 3.01} \\
\hline \multicolumn{6}{|l|}{ Equitability: 0.94} \\
\hline \multicolumn{6}{|l|}{ Total basal area: $41 \mathrm{~m}^{2} / \mathrm{ha}$} \\
\hline Plant species & IVI & CVI & $\begin{array}{l}\text { Abs. dens. } \\
\text { ind./ha }\end{array}$ & $\begin{array}{l}\text { Rel. dens. } \\
\text { ind./ha }\end{array}$ & Rel. dom. (\%) \\
\hline Apuleia leiocarpa & 24.40 & 20.23 & 40 & 8.33 & 11.90 \\
\hline Bowdichia virgilioides & 19.97 & 15.81 & 30 & 6.25 & 9.56 \\
\hline Parkia pendula & 19.06 & 14.89 & 20 & 4.17 & 10.72 \\
\hline Thyrsodium spruceanum & 18.88 & 14.71 & 40 & 8.33 & 6.38 \\
\hline Balizia pedicellaris & 18.81 & 14.65 & 50 & 10.42 & 4.23 \\
\hline Protium heptaphyllum & 18.42 & 14.26 & 40 & 8.33 & 5.92 \\
\hline Enterolobium contortisiliquum & 17.20 & 13.03 & 20 & 4.17 & 8.86 \\
\hline Eschweilera ovata & 16.61 & 12.44 & 30 & 6.25 & 6.19 \\
\hline Unidentified 1 & 15.16 & 10.99 & 20 & 4.17 & 6.82 \\
\hline Sloanea guianensis & 13.78 & 9.61 & 20 & 4.17 & 5.44 \\
\hline Ormosia sp. & 13.54 & 9.37 & 10 & 2.08 & 7.29 \\
\hline Symphonia globulifera & 12.06 & 7.90 & 20 & 4.17 & 3.73 \\
\hline Andira sp. & 10.95 & 6.78 & 20 & 4.17 & 2.62 \\
\hline Tapirira guianensis & 10.51 & 6.34 & 20 & 4.17 & 2.17 \\
\hline Simarouba amara & 8.65 & 4.49 & 10 & 2.08 & 2.40 \\
\hline Pouteria sp. 1 & 7.30 & 3.13 & 10 & 2.08 & 1.05 \\
\hline Ilex cf. sapotifolia & 7.19 & 3.02 & 10 & 2.08 & 0.94 \\
\hline Henrietta succosa & 7.04 & 2.87 & 10 & 2.08 & 0.79 \\
\hline Andira fraxinifolia & 7.04 & 2.87 & 10 & 2.08 & 0.79 \\
\hline Caesareacf. javitenses & 6.92 & 2.75 & 10 & 2.08 & 0.67 \\
\hline Maytenus distichophylla & 6.76 & 2.59 & 10 & 2.08 & 0.51 \\
\hline Brosimum guianensis & 6.73 & 2.56 & 10 & 2.08 & 0.48 \\
\hline Protium sp. & 6.53 & 2.36 & 10 & 2.08 & 0.28 \\
\hline Pouteria sp. 2 & 6.51 & 2.35 & 10 & 2.08 & 0.26 \\
\hline \multicolumn{6}{|l|}{ Ubaca } \\
\hline \multicolumn{6}{|l|}{ Total fragment area: $8.2 \mathrm{ha}$} \\
\hline \multicolumn{6}{|c|}{ Home range of the studied common marmoset group: 5.1 ha } \\
\hline \multicolumn{6}{|c|}{ Number of plant species: 16 (7 families) } \\
\hline \multicolumn{6}{|c|}{ Shannon Index: 2.52} \\
\hline \multicolumn{6}{|l|}{ Equitability: 0.91} \\
\hline \multicolumn{6}{|l|}{ Total basal area: $27 \mathrm{~m}^{2} / \mathrm{ha}$} \\
\hline Plant species & IVI & CVI & $\begin{array}{c}\text { Abs. dens. } \\
\text { ind./ha }\end{array}$ & $\begin{array}{l}\text { Rel. dens. } \\
\text { ind./ha }\end{array}$ & Rel. dom. (\%) \\
\hline Parkia pendula & 64.61 & 58.36 & 70 & 15.56 & 42.81 \\
\hline Thyrsodium spruceanum & 27.20 & 20.95 & 70 & 15.56 & 5.40 \\
\hline Margaritaria nobilis & 23.85 & 17.60 & 40 & 8.89 & 8.71 \\
\hline Brosimum guianensis & 20.52 & 14.27 & 50 & 11.11 & 3.16 \\
\hline Bowdichia virgilioides & 19.70 & 13.45 & 40 & 8.89 & 4.56 \\
\hline Dialium guianense & 19.56 & 13.31 & 30 & 6.67 & 6.64 \\
\hline Ocotea sp. & 18.17 & 11.92 & 30 & 6.67 & 5.26 \\
\hline Simarouba amara & 15.51 & 9.26 & 30 & 6.67 & 2.60 \\
\hline Eschweilera ovata & 15.21 & 8.96 & 20 & 4.44 & 4.52 \\
\hline Pouteria sp. & 15.03 & 8.78 & 10 & 2.22 & 6.56 \\
\hline Balizia pedicellaris & 14.60 & 8.35 & 10 & 2.22 & 6.13 \\
\hline Tapirira guianensis & 10.25 & 4 & 10 & 2.22 & 1.77 \\
\hline Diplotropis sp. & 9.26 & 3.01 & 10 & 2.22 & 0.79 \\
\hline Ocotea opifera & 8.94 & 2.69 & 10 & 2.22 & 0.47 \\
\hline
\end{tabular}


TABLE 2: Continued.

\begin{tabular}{|c|c|c|c|c|c|}
\hline Pogonophora schomburgkiana & 8.81 & 2.56 & 10 & 2.22 & 0.34 \\
\hline Andira fraxinifolia & 8.77 & 2.52 & 10 & 2.22 & 0.30 \\
\hline \multicolumn{6}{|l|}{ Calunga } \\
\hline \multicolumn{6}{|l|}{ Total fragment area: 7.1 ha } \\
\hline \multicolumn{6}{|c|}{ Home range of the studied common marmoset group: 5.6 ha } \\
\hline \multicolumn{6}{|c|}{ Number of plant species: 22 (12 families) } \\
\hline \multicolumn{6}{|l|}{ Shannon Index: 2.93} \\
\hline \multicolumn{6}{|l|}{ Equitability: 0.95} \\
\hline \multicolumn{6}{|l|}{ Total basal area: $37 \mathrm{~m}^{2} / \mathrm{ha}$} \\
\hline Plant species & IVI & CVI & $\begin{array}{l}\text { Abs. dens. } \\
\text { ind./ha }\end{array}$ & $\begin{array}{l}\text { Rel. dens. } \\
\text { ind./ha }\end{array}$ & Rel. dom. (\%) \\
\hline Parkia pendula & 42.50 & 37.95 & 40 & 9.52 & 28.43 \\
\hline Tapirira guianensis & 22.13 & 17.59 & 50 & 11.90 & 5.68 \\
\hline Lecythis pisonis & 18.76 & 14.22 & 10 & 2.38 & 11.84 \\
\hline Ilex cf. sapotifolia & 18.17 & 13.62 & 10 & 2.38 & 11.24 \\
\hline Symphonia globulifera & 17.73 & 13.19 & 30 & 7.14 & 6.04 \\
\hline Ocotea opifera & 15.67 & 11.13 & 30 & 7.14 & 3.98 \\
\hline Stryphnodendron pulcherrimum & 14.12 & 9.58 & 10 & 2.38 & 7.20 \\
\hline Bowdichia virgilioides & 13.85 & 9.30 & 20 & 4.76 & 4.54 \\
\hline Eschweilera ovata & 13.29 & 8.74 & 20 & 4.76 & 3.98 \\
\hline Cecropia pachystachya & 13.20 & 8.66 & 30 & 7.14 & 1.51 \\
\hline Thyrsodium spruceanum & 12.46 & 7.91 & 30 & 7.14 & 0.77 \\
\hline Balizia pedicellaris & 11.27 & 6.73 & 10 & 2.38 & 4.35 \\
\hline Protium heptaphyllum & 10.91 & 6.36 & 10 & 2.38 & 3.98 \\
\hline Myrcia sylvatica & 10.03 & 5.49 & 20 & 4.76 & 0.73 \\
\hline Rheedia gardneriana & 9.83 & 5.28 & 20 & 4.76 & 0.52 \\
\hline Pouteria sp. & 9.76 & 5.21 & 20 & 4.76 & 0.45 \\
\hline Simarouba amara & 9.05 & 4.51 & 10 & 2.38 & 2.13 \\
\hline Ficus sp. & 8.16 & 3.62 & 10 & 2.38 & 1.24 \\
\hline Lecythis lurida & 7.64 & 3.10 & 10 & 2.38 & 0.71 \\
\hline Guapira opposita & 7.17 & 2.63 & 10 & 2.38 & 0.25 \\
\hline Brosimum rubescens & 7.14 & 2.6 & 10 & 2.38 & 0.22 \\
\hline Vismia guianensis & 7.14 & 2.6 & 10 & 2.38 & 0.22 \\
\hline
\end{tabular}

IVI: Importance Value Index; CVI: Cover Value Index.

rainy season at both Jaguaré $\left(X^{2}=128.15, p<0.0001\right)$ and Ubaca $\left(X^{2}=65.68, p<0.0001\right)$, whereas "other" (fruit, flower, and prey) was significantly more exploited in the dry season at Jaguaré $\left(X^{2}=32.15, p=0.022\right)$ (no difference was detected at Ubaca, $\left.X^{2}=5.11, p=0.065\right)$. No correlation was detected between the number of feeding bouts on the two exploited tree species (Tapirira guianensis and Parkia pendula) and their structural variables (absolute density, relative density, relative dominance, Importance Value Index (IVI), and Cover Value Index (CVI)) (Table 4).

3.3. Home Range and Daily Movements. Mean home range size of the studied groups was 5.5 ha, with a maximum of 5.79 at Jaguaré and a minimum of 5.1 at Ubaca (Table 5; Figure 4). Home range sizes were not related to the size of the forest fragment $(S=2$, rho $=0.5, p=1)$, and seasonal differences in home range sizes were not significant $(U=4, \mathrm{df}=4$, $p=0.406)$.

Overall mean daily path length of the studied groups was $1,167 \pm 263 \mathrm{~m}$, and no statistically significant differences were detected in the daily path length among the studied groups
$(F=1.448, p=0.242)$ (Figure 5). No statistically significant differences were detected in the daily path length of the studied groups in the different seasons $(t=1.98, p=0.078)$, nor in any of the forest fragments when considered separately (Jaguaré: $t=0.196, p=0.846$; Calunga: $t=1.74 p=0.094$; no data available for the dry season in Ubaca) (Figure 5).

3.4. Activity Budget. Overall activity budget of the studied groups of common marmosets was dominated by resting. This constituted $37.8 \%(n=1,653)$ of activity at Jaguaré, $34.7 \%(n=1,294)$ at Ubaca, and $31.2 \%(n=1,110)$ at Calunga, whereas foraging was the least frequent activity, comprising only $7.7 \%(n=339)$ of the activity budget at Jaguaré, $7.7 \%(n=286)$ at Ubaca, and $10.1 \%(n=361)$ at Calunga (Figure 6).

The activity budget of the common marmosets showed statistically significant differences between the different seasons in all the three forest fragments; Jaguare $\left(X^{2}=138.92\right.$, $\mathrm{df}=4, p<0.0001)$, Ubaca $\left(X^{2}=131.38, \mathrm{df}=4, p<0.0001\right)$, and Calunga $\left(X^{2}=159.42, \mathrm{df}=4, p<0.0001\right)$. The three studied forest fragments had significantly higher levels 
TABLE 3: Food items consumed by the three studied groups of common marmosets (Callithrix jacchus) in the studied forest fragments at Usina Trapiche, Northeast Brazil, between January and October 2010.

\begin{tabular}{|c|c|c|c|c|c|c|c|}
\hline \multirow{2}{*}{ Plant species } & \multirow{2}{*}{ Status } & \multicolumn{3}{|c|}{ Resource } & \multicolumn{2}{|c|}{ Month when exploited } & \multirow{2}{*}{ Forest fragment where exploited } \\
\hline & & Fruit & Gum & Flower & Dry & Wet & \\
\hline \multicolumn{8}{|l|}{ Anacardiaceae } \\
\hline Tapirira guianensis & Native & & $\mathrm{X}$ & & $\begin{array}{l}\text { Jan./Feb./Mar/ } \\
\text { Apr./Sep./Oct. }\end{array}$ & $\begin{array}{l}\text { May/Jun./ } \\
\text { Jul./Aug. }\end{array}$ & $\mathrm{U}, \mathrm{J}, \mathrm{C}$ \\
\hline Thyrsodium spruceanum & Native & & & & & & \\
\hline \multicolumn{8}{|l|}{ Aquifoliaceae } \\
\hline Ilex cf. sapotifolia & Native & & & & & & \\
\hline \multicolumn{8}{|l|}{ Burseraceae } \\
\hline Protium heptaphyllum & Native & & & & & & \\
\hline \multicolumn{8}{|l|}{ Cecropiaceae } \\
\hline Cecropia glaziovii & Native & $\mathrm{X}$ & & & Jan./Feb. & & $\mathrm{U}$ \\
\hline Cecropia pachystachya & Native & & & & & & \\
\hline \multicolumn{8}{|l|}{ Celastraceae } \\
\hline Maytenus distichophylla & Native & & & & & & \\
\hline \multicolumn{8}{|l|}{ Clusiaceae } \\
\hline Rheedia gardneriana & Native & & & & & & \\
\hline Symphonia globulifera & Native & & & & & & \\
\hline \multicolumn{8}{|l|}{ Elaeocarpaceae } \\
\hline \multicolumn{8}{|l|}{ Sloanea guianensis } \\
\hline \multicolumn{8}{|l|}{ Euphorbiaceae } \\
\hline Margaritaria nobilis & Native & & & & & & \\
\hline Pogonophora schomburgkiana & Native & & & & & & \\
\hline \multicolumn{8}{|l|}{ Fabaceae } \\
\hline Andira fraxinifolia & Native & & & & & & \\
\hline Andira sp. & Native & & & & & & \\
\hline Apuleia leiocarpa & Native & & & & & & \\
\hline Balizia pedicellaris & Native & & & & & & \\
\hline Bowdichia virgilioides & Native & & & & & & \\
\hline Dialium guianense & Native & $\mathrm{X}$ & & & & May/Jun./Jul. & $\mathrm{J}, \mathrm{C}$ \\
\hline Diplotropis sp. & Native & & & & & & \\
\hline Enterolobium contortisiliquum & Native & & & & & & \\
\hline Ormosia sp. & Native & & & & & & \\
\hline Parkia pendula & Native & & $\mathrm{X}$ & & $\begin{array}{l}\text { Jan./Feb./ } \\
\text { Mar./Apr. }\end{array}$ & & $\mathrm{U}, \mathrm{J}, \mathrm{C}$ \\
\hline Stryphnodendron pulcherrimum & Native & & & & & & \\
\hline \multicolumn{8}{|c|}{ Flacourtiaceae } \\
\hline Casearia javitensis & Native & & & & & & \\
\hline \multicolumn{8}{|l|}{ Hypericaceae } \\
\hline Vismia guianensis & Native & & & & & & \\
\hline \multicolumn{8}{|l|}{ Lauraceae } \\
\hline Ocotea opifera & Native & & & & & & \\
\hline Ocotea sp. & Native & & & & & & \\
\hline \multicolumn{8}{|l|}{ Lecythidaceae } \\
\hline Eschweilera ovata & Native & $\mathrm{X}$ & & & Jan./Feb. & & $\mathrm{U}$ \\
\hline Lecythis lurida & Native & & & & & & \\
\hline Lecythis pisonis & Native & & & & & & \\
\hline
\end{tabular}


TABLE 3: Continued.

\begin{tabular}{|c|c|c|c|c|c|c|c|}
\hline \multirow{2}{*}{ Plant species } & \multirow{2}{*}{ Status } & \multicolumn{3}{|c|}{ Resource } & \multicolumn{2}{|c|}{ Month when exploited } & \multirow{2}{*}{ Forest fragment where exploited } \\
\hline & & Fruit & Gum & Flower & Dry & Wet & \\
\hline \multicolumn{8}{|l|}{ Melastomataceae } \\
\hline Henrietta succosa & Native & & & $\mathrm{X}$ & Feb. & & $\mathrm{U}$ \\
\hline Miconia sp. & Native & $\mathrm{X}$ & & & & Apr. & $\mathrm{J}$ \\
\hline \multicolumn{8}{|l|}{ Moraceae } \\
\hline Brosimum guianensis & Native & $\mathrm{X}$ & & & & Mar. & $\mathrm{J}$ \\
\hline Brosimum rubescens & Native & & & & & & \\
\hline Ficus sp. & Native & & & & & & \\
\hline \multicolumn{8}{|l|}{ Myrtaceae } \\
\hline Myrcia sylvatica & Native & & & & & & \\
\hline Syzygium jambolanum & Introduced & $\mathrm{X}$ & & & & Jan./Feb. & $\mathrm{U}$ \\
\hline \multicolumn{8}{|l|}{ Nyctaginaceae } \\
\hline Guapira opposita & Native & & & & & & \\
\hline \multicolumn{8}{|l|}{ Sapotaceae } \\
\hline Micropholis compacta & Native & $\mathrm{X}$ & & & & Sep. & $\mathrm{C}$ \\
\hline Pouteria sp. 1 & Native & & & & & & \\
\hline Pouteria sp. 2 & Native & & & & & & \\
\hline \multicolumn{8}{|l|}{ Simaroubaceae } \\
\hline Simarouba amara & Native & & & & & & \\
\hline \multicolumn{8}{|l|}{ Animal protein } \\
\hline \multicolumn{8}{|l|}{ Homoptera } \\
\hline Cicadidae & Native & & & Insect & Mar., Apr. & & $\mathrm{J}$ \\
\hline Lepidoptera & Native & & & Insect & Jan. & & $\mathrm{U}$ \\
\hline
\end{tabular}

TABLE 4: Relationship between the number of gum feeding bouts by the common marmosets on the two exploited tree species and their structural variables in the studied forest fragments at Usina Trapiche, Northeast Brazil.

\begin{tabular}{|c|c|c|c|}
\hline Tree species & Dependent variable & Independent variable & Spearman correlation coefficient \\
\hline \multirow{5}{*}{ Tapirira guianensis } & \multirow{5}{*}{ Number of feeding bouts $\mathrm{X}$} & Absolute density (ind./ha) & $S=0$, rho $=1, p=0.333$ \\
\hline & & Relative density (ind./ha) & $S=0$, rho $=1, p=0.333$ \\
\hline & & Relative dominance (\%) & $S=0$, rho $=1, p=0.333$ \\
\hline & & Importance Value Index (IVI) & $S=0$, rho $=1, p=0.333$ \\
\hline & & Cover Value Index (CVI) & $S=0$, rho $=1, p=0.333$ \\
\hline \multirow{5}{*}{ Parkia pendula } & \multirow{5}{*}{ Number of feeding bouts $\mathrm{X}$} & Absolute density (ind./ha) & $S=2$, rho $=0.5, p=1$ \\
\hline & & Relative density (ind./ha) & $S=2$, rho $=0.5, p=1$ \\
\hline & & Relative dominance (\%) & $S=2$, rho $=0.5, p=1$ \\
\hline & & Importance Value Index (IVI) & $S=2$, rho $=0.5, p=1$ \\
\hline & & Cover Value Index (CVI) & $S=2$, rho $=0.5, p=1$ \\
\hline \multirow{5}{*}{ Tapirira guianensis and Parkia pendula } & \multirow{5}{*}{ Number of feeding bouts $\mathrm{X}$} & Absolute density (ind./ha) & $S=36$, rho $=-0.03, p=0.957$ \\
\hline & & Relative density (ind./ha) & $S=36$, rho $=-0.03, p=0.957$ \\
\hline & & Relative dominance (\%) & $S=56$, rho $=-0.60, p=0.242$ \\
\hline & & Importance Value Index (IVI) & $S=46$, rho $=-0.31, p=0.564$ \\
\hline & & Cover Value Index (CVI) & $S=46$, rho $=-0.31, p=0.564$ \\
\hline
\end{tabular}

of resting, locomotion, and social activity in the dry season (with the exception of resting in Ubaca) and higher levels of feeding and foraging in the wet season (Table 6; Figure 6).

\section{Discussion}

The Atlantic Forest of northeastern Brazil has lost more than $50 \%$ of the total tree species, and one-third of these were large/very large-fruited and large-seeded species [6-8]. This suggests that there may be very little or no food available to the remaining frugivorous vertebrates. This situation is likely to be even more pronounced in very small forest fragments and may ultimately have caused the extirpation of various mammal species (including all the large-bodied ones) $[9,10$, 48]. 

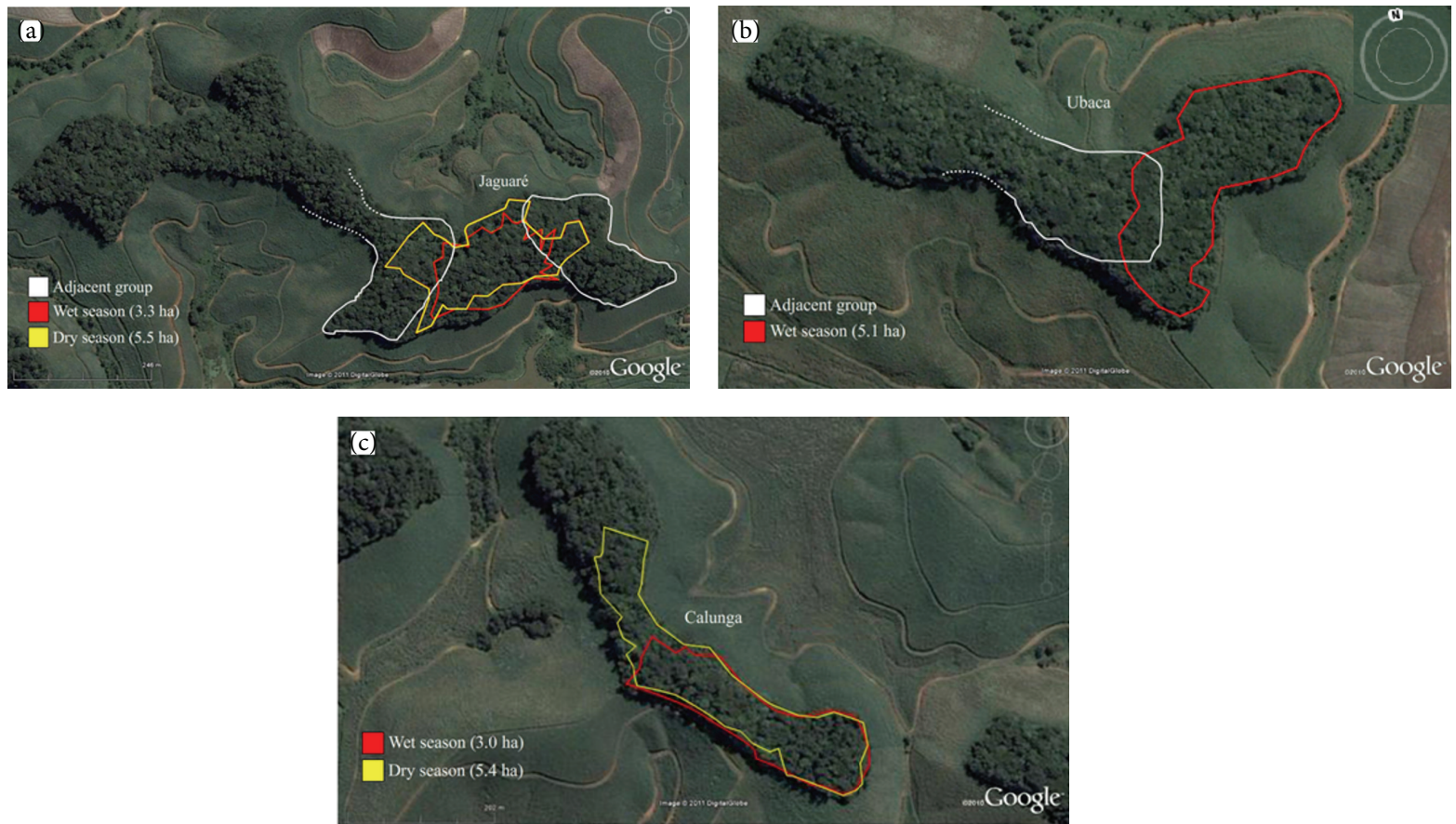

FiguRE 4: Home range of the study groups in each season at Usina Trapiche, in the Atlantic Forest of Northeast Brazil: (a) Jaguaré, (b), Ubaca, and (c) Calunga. Images obtained from Google Earth.

TABLE 5: Home range of the studied common marmoset groups at Usina Trapiche, Northeast Brazil.

\begin{tabular}{lcccc}
\hline \multirow{2}{*}{ Forest fragment } & \multirow{2}{*}{ Area (ha) } & \multicolumn{3}{c}{ Home range size } \\
& & Dry & Wet & Total \\
\hline Jaguaré & 10 & 5.49 & 3.29 & 5.79 \\
Ubaca & 8.2 & & 5.1 & 5.1 \\
Calunga & 7.1 & 5.43 & 3.01 & 5.61 \\
\hline
\end{tabular}

The forest fragments studied here appear to represent one of the worst scenarios possible. For instance, thirty years ago Pontes and Soares [13, Unpubl. data.] recorded 52 tree species in the home range of a single group of common marmosets in a 373 ha forest fragment at Dois Irmãos Botanical Garden, an urban forest similar in structure and disturbance levels to those in the current study. In the tiny forest fragments examined in the current study, however, between 16 and 24 tree species were registered. This is only between $30 \%$ and $46 \%$ of what Pontes and Soares [13] recorded. Additionally, the common marmosets in this study had no access to human habitations and, consequently, did not benefit from the additional supply of exotic fruits from orchards and backyards (as in Pontes and Soares [13] where, in addition to the much higher number of tree species exploited by the latter, $19 \%$ of them were introduced and were providing a supplemental fruit supply).

Of tree species recorded by Pontes and Soares [13], 17 species were exploited (nine for fruit, four for gum, and four for fruit and gum), with fruit representing the most exploited resource $(61.5 \%)$, followed by gum $(28.7 \%)$ and insect $(9.8 \%)$. In a more recent study in the same 373 ha forest remnant, Silva et al. [16] found that the most exploited
TABLE 6: Seasonal differences in the behaviors of the common marmosets in the three studied groups at Usina Trapiche, Northeast Brazil.

\begin{tabular}{|c|c|c|c|c|}
\hline \multirow{2}{*}{ Forest fragment } & \multicolumn{3}{|c|}{ Number of records } & \multirow{2}{*}{ Significance } \\
\hline & Dry & Wet & Total & \\
\hline \multicolumn{5}{|l|}{ Jaguaré } \\
\hline Resting & 872 & 781 & 1653 & 0.027 \\
\hline Locomotion & 743 & 651 & 1394 & 0.015 \\
\hline Social & 301 & 237 & 538 & 0.007 \\
\hline Feeding & 105 & 328 & 433 & $<0.0001$ \\
\hline Foraging & 148 & 191 & 339 & 0.022 \\
\hline Total & 2170 & 2205 & 4375 & \\
\hline \multicolumn{5}{|l|}{ Ubaca } \\
\hline Resting & 610 & 684 & 1294 & 0.042 \\
\hline Locomotion & 716 & 475 & 1191 & $<0.0001$ \\
\hline Social & 237 & 236 & 473 & 1 \\
\hline Feeding & 144 & 307 & 451 & $<0.0001$ \\
\hline Foraging & 103 & 183 & 286 & $<0.0001$ \\
\hline Total & 1813 & 1890 & 3703 & \\
\hline \multicolumn{5}{|l|}{ Calunga } \\
\hline Resting & 620 & 490 & 1110 & $<0.0001$ \\
\hline Locomotion & 466 & 366 & 832 & $<0.0001$ \\
\hline Feeding & 207 & 498 & 705 & $<0.0001$ \\
\hline Social & 284 & 269 & 553 & 0.552 \\
\hline Foraging & 143 & 218 & 361 & $<0.0001$ \\
\hline Total & 1720 & 1841 & 3561 & \\
\hline
\end{tabular}

${ }^{*}$ Significant differences according to an exact binomial test in bold.

resource was gum $(61.99 \%)$, followed by leaves, flower, seeds (9.7\%), and fruit (2.9\%). The lack of animal matter could 


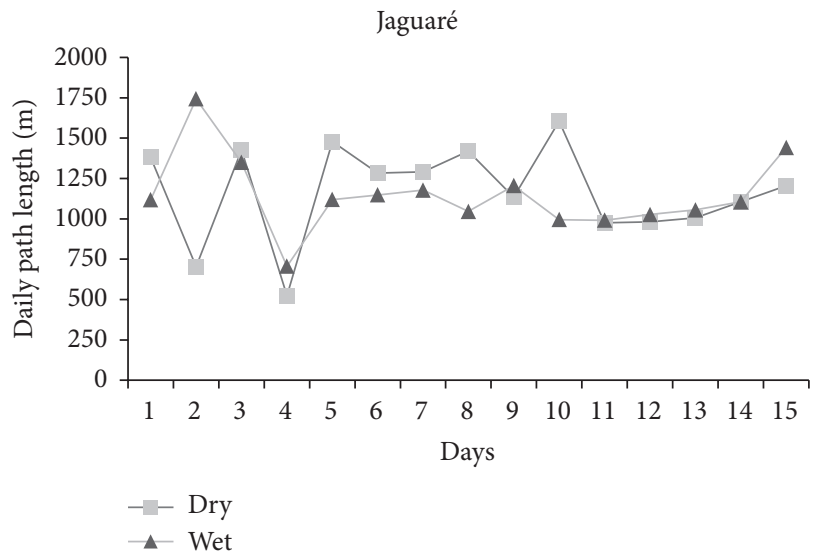

(a)

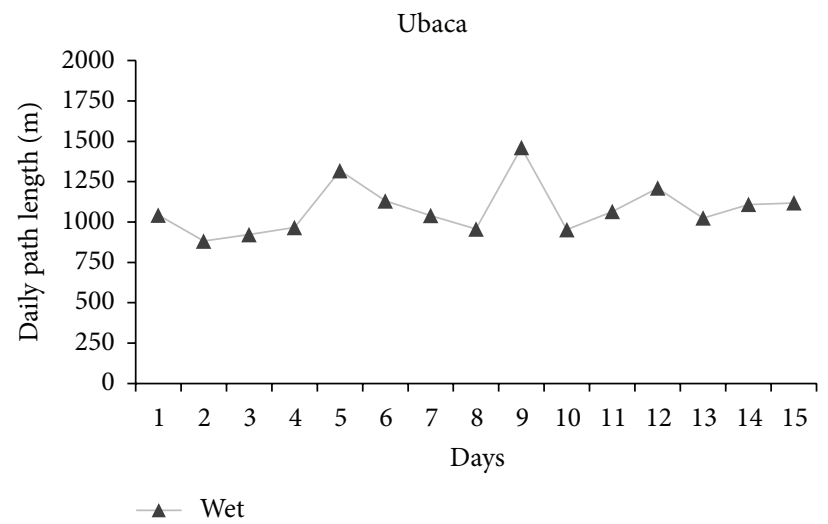

(b)

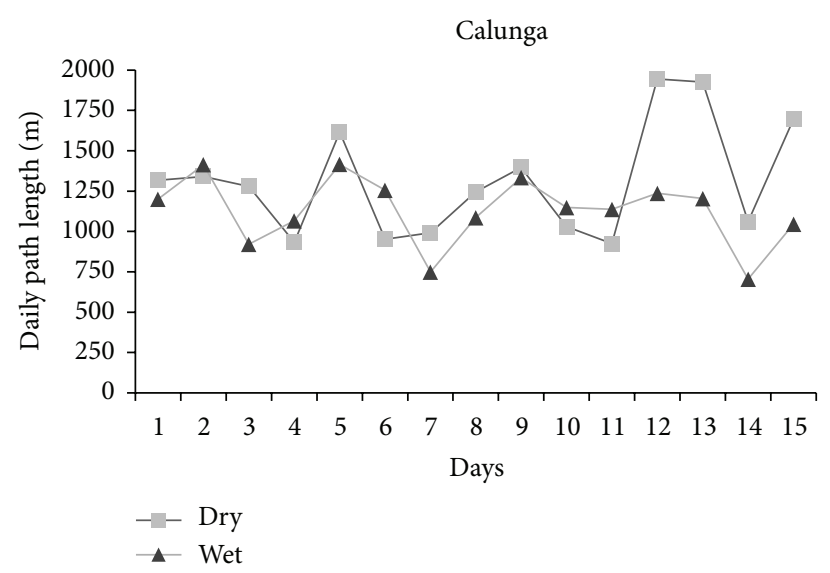

(c)

FIGURE 5: Daily path length of the groups throughout the study at Usina Trapiche, in the Atlantic Forest of Northeast Brazil: (a) Jaguaré, (b) Ubaca, and (c) Calunga.

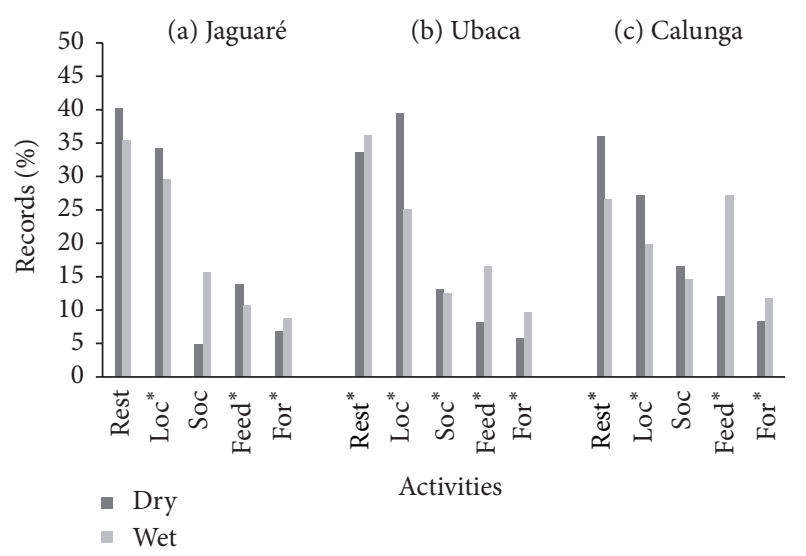

FIgUre 6: Activity budget of the studied groups at Usina Trapiche, in the Atlantic Forest of Northeast Brazil: (a) Jaguaré, (b) Ubaca, and (c) Calunga. Rest $=$ resting, $\operatorname{Loc}=$ locomotion, Soc $=$ social, Feed $=$ feeding, and For $=$ foraging. ${ }^{*} p<0.05$.

result from the systematic human impact to which these remnants have been subjected [49], which has imposed severe food constraints on the common marmosets.
In this environment, the studied groups had one of the poorest and least diverse diets of any groups inhabiting a natural habitat, not only when compared to Pontes and Soares [13], but also in comparison to other studies, either others with common marmosets $[15,50,51]$ or those with other callitrichids $[11,14,21,26]$. Their diet in these very small forest fragments was extremely simplified and based almost exclusively on tree gum (up to $98.3 \%$ ), of only two tree species, Tapirira guianensis and Parkia pendula. These, it appears, were the only reliable food sources, and so there was only a very small percentage of nongum food items.

Relatively high rates of gum feeding have already been recorded in the Atlantic Forest of northeastern Brazil, both for common marmosets ( $62 \%$ of feeding bouts) [16] and for other callitrichids (up to $87 \%$ of their feeding bouts [2124]). The values presented here are, nevertheless, some of the highest ever reported for gum feeding, being higher even than those reported for common marmosets in dryscrub Caatinga forest (around 50\% of the feeding bouts) [30], and for C. penicillata in the xeromorphic semideciduous woodlands of the Cerrado and Cerradão (between $45 \%$ and 65\%) [34]. This suggests that the animals in the studied fragments are living in very depauperate forest fragments, 
where tree species diversities were some of the lowest ever recorded for a tropical rainforest habitat, where almost no fruit or insects were available, and only two tree species provided exudates.

Thus, instead of a more typical foraging-dominated activity budget $[15,18,28,29]$, the activity pattern of the study groups had one of the highest percentages of resting ever recorded, even when compared to other callitrichids living in the much more climatically inhospitable Cerrado $[25,52]$ or at high altitudes [23]. This probably resulted from the fact that the gum is easily obtained but very difficult to digest. Gum (especially, as in the current study, when it comes from a few close-by individuals of only two species) is an easily obtained food, resulting in the three groups having one of the lowest rates of foraging ever recorded for callitrichids, leaving much more spare time for other activities, such as resting and social activities.

However, in the wet season, when Parkia pendula did not have pods and so was not a source of exudates, a considerable decrease in gummivory was detected, which caused an equivalent increase in foraging and feeding. The temporal patterning of feeding bouts in these small forest fragments was, nevertheless, similar to other studies, with a peak early in the morning and another one late in the afternoon and with the lowest rates being in the middle of the day, when it is common for the animals to rest $[13,15$, $18,28,29]$. These peaks have been shown to be essential for energy intake (fruit in the morning just after fast of a long night asleep) and gum just before entering their sleeping tree (with a long night ahead to digest a resource that requires fermentation) $[13,15,19]$.

In primates, home range size is often greater in areas subjected to high degrees of human interference $[12,15]$. This is the case in the current study in highly impacted, small, and isolated forest fragments; here home ranges reached up to 5.79 ha, slightly larger than what has been reported so far for common marmoset. Interestingly, the group at Calunga were the only one inhabiting that forest fragment and the maximum size of their home range was 5.4 ha, leaving the remaining 7.1 ha forest fragment unoccupied. Thus, we hypothesize that the home range sizes in this study may well be close to the maximum to which the animals can increase their home ranges, even though they had to rely heavily on the exploitation of gum.

Home range size of common marmosets may vary according to seasonal shifts in food availability [38, 39]. We failed to detect any statistically significant differences between wet and dry season. This is unsurprising since in the studied forests very little or no fruit was available, with the only reliable food sources being the highly predictable gum trees. The slight observable difference between the seasons, however, may have resulted from the fact that in the wet season the common marmosets concentrated their activities around gum-providing Tapirira guianensis clusters, whereas in the dry season they were able to exploit the more evenly distributed gum-providing Parkia pendula individuals.

Mean daily path travelled is generally influenced by seasonal variation in the availability of food, particularly fruit $[12,39]$. In this study, daily routes travelled by the common marmosets were between 1,052 and $1,219 \mathrm{~m}$ and so did not differ significantly from distances reported by Alonso and Langguth [15] and Digby and Barreto [28], possibly because they did not have to travel more extensively to find food, in this case, gum trees. By the same token, we also failed to detect any statistically significant differences between wet and dry season.

\section{Conclusions}

This study shows that survival by common marmosets in the 21st century in these small, isolated, irregular and depauperate forest fragments of the Atlantic forest of Northeast Brazil is only achieved by a remarkable increase of the frequency with which they exploit tree gum, compensating for the almost complete lack of other food items. As a consequence of exploiting an easily obtainable food, they travelled and foraged what appears to be the least possible. These primates are probably living at the edge of what is physiologically possible for the species, doing their utmost effort to survive in this hotspot's hotspot.

\section{Conflict of Interests}

The authors declare that there is no conflict of interests regarding the publication of this paper.

\section{Acknowledgments}

The authors are grateful to the administration of the Trapiche mill, within which the forest fragments occur, especially to Mrs. Evânia Freire and Dr. Mário Jorge Seixas Aguiar, for permission for the study to take place in the area and for infrastructure and support essential for its success. The Science Foundation of the State of Pernambuco (FACEPE) granted a postgraduate scholarship to Herbert Leonardo Nascimento Pinheiro. They are indebted to Professor Dr. J. C. Bicca-Marques for important suggestions and corrections to this paper, as well as to two anonymous reviewers who provided highly constructive suggestions. Adrian A. Barnett helped with the English.

\section{References}

[1] G. T. Prance, "Forest refuges: evidences from woody angiosperms," in Biological Diversification in the Tropics, G. T. Prance, Ed., pp. 137-158, Columbia University Press, New York, NY, USA, 1982.

[2] J. M. C. Silva and C. H. M. Casteletti, "Status of the biodiversity of the Atlantic forest of Brazil," in The Atlantic Forest of South America: Biodiversity Status, Threats and Outlook, C. GalindoLeal and I. G. Câmara, Eds., pp. 43-59, Island Press and CABS, Washington, DC, USA, 2003.

[3] M. F. Stevenson and A. B. Rylands, "The marmosets, Genus Callithrix," in Ecology and Behavoiur of Neotropical Primates-2, A. R. Mittermeier, A. B. Rylands, A. Coimbra-Filho, and B. A. G. Fonseca, Eds., pp. 349-353, World Wildlife Fund, Washington, DC, USA, 1988. 
[4] C. Carnaval, M. J. Hickerson, C. F. B. Haddad, M. T. Rodrigues, and C. Moritz, "Stability predicts genetic diversity in the brazilian atlantic forest hotspot," Science, vol. 323, no. 5915, pp. 785-789, 2009.

[5] V. M. Viana, A. J. Tabanez, and J. L. Batista, "Dynamics and restoration of forest fragments in the Brazilian Atlantic moist forest," in Tropical Forest Remnants: Ecology, Management, and Conservation of Fragmented Communities, W. F. Laurance and R. O. Bierregaard Jr., Eds., pp. 351-365, University of Chicago Press, Chicago, Ill, USA, 1997.

[6] J. M. C. Da Silva and M. Tabarelli, "Tree species impoverishment and the future flora of the Atlantic forest of northeast Brazil," Nature, vol. 404, no. 6773, pp. 72-74, 2000.

[7] M. A. Oliveira, A. S. Grillo, and M. Tabarelli, "Forest edge in the Brazilian Atlantic forest: drastic changes in tree species assemblages," Oryx, vol. 38, no. 4, pp. 389-394, 2004.

[8] B. A. Santos, C. A. Peres, M. A. Oliveira, A. Grillo, C. P. Alves-Costa, and M. Tabarelli, "Drastic erosion in functional attributes of tree assemblages in Atlantic forest fragments of northeastern Brazil," Biological Conservation, vol. 141, no. 1, pp. 249-260, 2008.

[9] A. R. Mendes Pontes, P. H. A. Peres, I. C. Normande, and C. M. Brazil, "Mamíferos," in Diversidade Biológica e Conservação da Floresta Atlântica ao Norte do São Francisco, K. C. Porto, J. S. Almeida-Cortez, and M. Tabarelli, Eds., pp. 10-50, Ministério do Meio Ambiente-Série Biodiversidade, Brasília, Brazil, 2006.

[10] A. P. da Silva Jr. and A. R. Mendes Pontes, "The effect of a mega-fragmentation process on large mammal assemblages in the highly-threatened Pernambuco Endemism Centre, northeastern Brazil," Biodiversity and Conservation, vol. 17, no. 6, pp. 1455-1464, 2008.

[11] A. B. Rylands and D. S. Faria, "Habitats, feeding ecology, and home range size in the genus Callithrix," in Marmosets and Tamarins: Systematics, Behaviour, and Ecology, A. B. Rylands, Ed., pp. 262-272, Oxford University Press, Oxford, UK, 1993.

[12] A. R. M. Pontes and M. A. O. Monteiro da Cruz, "Home range, intergroup transfers, and reproductive status of common marmosets Callithrix jacchus in a forest fragment in NorthEastern Brazil," Primates, vol. 36, no. 3, pp. 335-347, 1995.

[13] A. R. M. Pontes and M. L. Soares, "Sleeping sites of common marmosets (Callithrix jacchus) in defaunated urban forest fragments: a strategy to maximize food intake," Journal of Zoology, vol. 266, no. 1, pp. 55-63, 2005.

[14] M. F. Stevenson and A. B. Rylands, "The marmoset genus," in Ecology and Behaviour of Neotropical Primates, R. A. Mittermeier, A. B. Rylands, A. F. Coimbra-Filho, and G. A. B. Fonseca, Eds., pp. 131-223, World Wildlife Fund, Washington, DC, USA, 1988.

[15] C. Alonso and A. Langguth, "Ecologia e comportamento de Callithix jacchus (Primates: Callitrichidae) numa ilha de floresta Atlântica," Revista Nordestina de Biologia, vol. 6, no. 2, pp. 105137, 1989.

[16] J. M. Silva, J. R. Albuquerque, and M. A. Borstelmann, "Consumo de itens de origem vegetal por um grupo de Callithrix jacchus habitantes do Parque Estadual Dois Irmãos," in Proceedings of the 10th Jornada de Ensino, Pesquisa e Extensão (JEPEX '10), pp. 18-20, Universidade Federal Rural de Pernambuco, Recife, Brazil, 2010.

[17] W. Maier, C. Alonso, and A. Langguth, "Field observations on Callithrix jacchus jacchus L.," Zeitschrift Saugetierkunde, vol. 47, pp. 334-346, 1982.
[18] K. C. S. Cavalcanti, Comportamento alimentar de Callithrix jacchus (Callitrichidae, Primates) em mata secundária e ambiente alterado [M.Phil. thesis], Universidade Federal do Rio Grande do Norte, Natal, Brazil, 2002.

[19] L. T. Nash, "Dietary, behavioral, and morphological aspects of gummivory in primates," Yearbook of Physical Anthropology, vol. 29, pp. 113-137, 1986.

[20] M. L. Power, "Nutritional and digestive challenges to being a gum-feeding primate," in The Evolution of Exudativory in Primates, A. M. Burrows and L. T. Nash, Eds., pp. 25-44, Springer, Heidelberg, Germany, 2010.

[21] S. F. Ferrari, The behaviour and ecology of the buffy-headed marmoset, Callithrix flaviceps (O. Thomas, 1903) [Ph.D. thesis], University College London, London, UK, 1988.

[22] S. F. Ferrari and A. B. Rylands, "Activity budgets and differential visibility in field studies of three marmosets (Callithrix spp.)," Folia Primatologica, vol. 63, no. 2, pp. 78-83, 1994.

[23] H. K. M. Corrêa, P. E. G. Coutinho, and S. F. Ferrari, "Betweenyear differences in the feeding ecology of highland marmosets (Callithrix aurita and Callithrix flaviceps) in south-eastern Brazil," Journal of Zoology, vol. 252, no. 4, pp. 421-427, 2000.

[24] S. F. Ferrari, H. K. M. Corrêa, and P. E. G. Coutinho, "Ecology of the 'Southern' marmosets (Callithrix aurita and Callithrix flaviceps): how different, how similar?" in Adaptive Radiations of Neotropical Primates, M. A. Norconk, A. L. Rosenberger, and P. A. Garber, Eds., pp. 157-172, Plenum Press, New York, NY, USA, 1996.

[25] M. M. Martins, "Feeding ecology of Callithrix aurita in a forest fragment of Minas Gerais," Neotropical Primates, vol. 6, no. 4, pp. 126-127, 1998.

[26] M. M. Martins and E. Z. F. Setz, "Diet of buffy tuftedeared marmosets (Callithrix aurita) in a forest fragment in southeastern Brazil," International Journal of Primatology, vol. 21, no. 3, pp. 467-476, 2000.

[27] L. C. Melo, M. A. O. M. da Cruz, and Z. F. Fernandez, "Composição química de exsudatos explorados pelo Callithrix jacchus e sua relação com a marcação de cheiro," in A Primatologia no Brasil-4, M. B. C. Souza and A. A. L. Menezes, Eds., pp. 43-53, Editora da Universidade Federal do Rio Grande do Norte, Natal, Brazil, 1997.

[28] L. J. Digby and C. Barreto, "Activity and ranging patterns in common marmosets (Callithrix jacchus)," in Adaptive Radiations of Neotropical Primates, M. A. Norconk, A. L. Rosenberger, and P. A. Garber, Eds., pp. 173-186, Plenum Press, New York, NY, USA, 1996.

[29] M. C. Nascimento, Influência da presença dos filhotes e do tamanho do grupo nas atividades de um grupo silvestre de sagüis (Callithrix jacchus) [M.Phil thesis], Universidade Federal do Rio Grande do Norte, Natal, Brazil, 1997.

[30] I. G. Martins, Padrão de Atividades do Sagüi Callithrix jacchus numa Área de Caatinga [M.Phil. thesis], Universidade Federal do Rio Grande do Norte, Natal, Brazil, 2007.

[31] B. E. Raboy, G. R. Canale, and J. M. Dietz, "Ecology of Callithrix kuhlii and a review of eastern Brazilian marmosets," International Journal of Primatology, vol. 29, no. 2, pp. 449-467, 2008.

[32] A. Abbehusen, R. M. L. Silva, and C. E. Barreto, "Dieta e área de uso do sagüi-da-cara-branca (Callithrix geoffroyi) em Porto Seguro, Bahia," in A Primatologia no Brasil-10, J. C. Bicca-Marques, Ed., pp. 375-385, Sociedade Brasileira de Primatologia, Rio Grande do Sul, Brazil, 2007. 
[33] G. A. B. da Fonseca and T. E. Lacher Jr., "Exudate-feeding by Callithrix jacchus penicillata in semideciduous woodland (Cerradão) in central Brazil," Primates, vol. 25, no. 4, pp. 441449, 1984.

[34] V. A. David, Padrão de atividades, ecologia alimentar e área de vida em um grupo de Callithrix penicillata (HUMBOLDT, 1812) (Primates, Callitrichidae) (Sagui de tufos pretos) [Ph.D. thesis], Universidade Estadual Paulista, São Paulo, Brazil, 2005.

[35] R. C. Hubrecht, "Home-range size and use and territorial behavior in the common marmoset, Callithrix jacchus jacchus, at the tapacura field station, recife, Brazil," International Journal of Primatology, vol. 6, no. 5, pp. 533-550, 1985.

[36] C. C. S. Castro, A. A. Araújo, and C. Alho, "Influência da distribuição e disponibilidade de frutos na dieta e uso do espaço em sagüis-do-Nordeste (Callithrix jacchus)," in A Primatologia no Brasil-7, C. Alonso and A. Langguth, Eds., pp. 65-80, Federal University of Paraíba, Paraíba, Brazil, 2000.

[37] L. J. Digby and C. E. Barreto, "Social organization in a wild population of Callithrix jacchus," Folia Primatologica, vol. 61, no. 3, pp. 123-134, 1993.

[38] C. E. Scanlon, N. R. Chalmers, and M. A. O. Monteiro-da-Cruz, "Home range use and the exploitation of gum in the marmoset Callithrix jacchus jacchus," International Journal of Primatology, vol. 10, no. 2, pp. 123-136, 1989.

[39] M. C. C. Cabral, Uso da área domiciliar de um grupo de Callithix jacchus (Callithrichidae, Primates) na Estação Ecológica do Tapacurá-Pernambuco, Brazil [B.Sc. thesis], Universidade Federal Rural de Pernambuco, Recife, Brazil, 1989.

[40] A. B. Rylands, "Sympatric Brazilian callitrichids: the black tufted-ear marmoset, Callithrix kuhli and the golden-headed lion tamarin, Leontopithecus chrysomelas," Journal of Human Evolution, vol. 18, no. 7, pp. 679-695, 1989.

[41] A. T. Oliveira-Filho and M. A. L. Fontes, "Patterns of floristic differentiation among atlantic forests in southeastern Brazil and the influence of climate," Biotropica, vol. 32, no. 4, pp. 793-810, 2001.

[42] Centro de Previsão do Tempo e Estudos Climáticos (CPTEC), "Precipitação climática," CPTEC, 2011, http://climal.cptec.inpe .br/monitoramentobrasil/pt.

[43] M. E. Yamamoto, "Comportamento social do Gênero Callithrix em cativeiro," in A Primatologia no Brasil-3, A. B. Rylands and A. T. Bernardes, Eds., pp. 63-81, Sociedade Brasileira de Primatologia and Fundação Biodiversitas, Minas Gerais, Brazil, 1991.

[44] D. Muller-Dombois and H. Ellenberg, Aims and Methods of Vegetation Ecology, John Wiley \& Sons, New York, NY, USA, 1974.

[45] G. J. Shepherd, Fitopac-Manual do Usuário, Universidade Estadual de Campinas, Campinas, Brazil, 2006.

[46] J. Altmann, "Observational study of behavior: sampling methods," Behaviour, vol. 49, no. 3-4, pp. 227-267, 1974.

[47] J. G. Kie, J. A. Baldwin, and C. J. Evans, "Calhome: a program for estimating animal home ranges," Wildlife Society Bulletin, vol. 24, no. 2, pp. 342-344, 1996.

[48] P. H. Asfora and A. R. M. Pontes, "The small mammals of the highly impacted North-eastern Atlantic Forest of Brazil, Pernambuco Endemism Center," Biota Neotropica, vol. 9, no. 1, pp. 31-35, 2009.

[49] A. R. Mendes Pontes, Amazonia and Other Forests of Brazil, Janus Publishing, London, UK, 2009.
[50] C. E. Scalon, M. A. O. Monteiro da Cruz, and A. B. Rylands, "Exploração de exsudatos vegetais pelo sagui-comum, Callithrix jacchus," in A Primatologia no Brasi-3, A. B. Rylands and A. T. Bernardes, Eds., p. 197, Sociedade Brasileira de Primatologia and Fundação Biodiversitas, Minas Gerais, Brazil, 1991.

[51] K. C. S. Veríssimo, Área domiciliar e utilização de recursos alimentares por saguis, Callithrix jacchus na Reserva Particular do Patrimônio Natural (RPPN) Nossa Senhora do Outeiro de Maracaípe, Ipojuca-PE [M.Phil. thesis], Universidade Federal de Pernambuco, Recife, Brazil, 2007.

[52] A. Odalia-Rímoli, K. C. Cazzadore, and J. J. Rímoli, “Comportamento alimentar do sagüi-de-tufo-preto (Callithrix penicillata É. Geoffroy, 1812; Cebidae, Callitrichinae, Primates) em um fragmento urbano de cerrado, MS," in X Congresso Brasileiro de Primatologia, p. 83, Pará, Brazil, November 2002. 

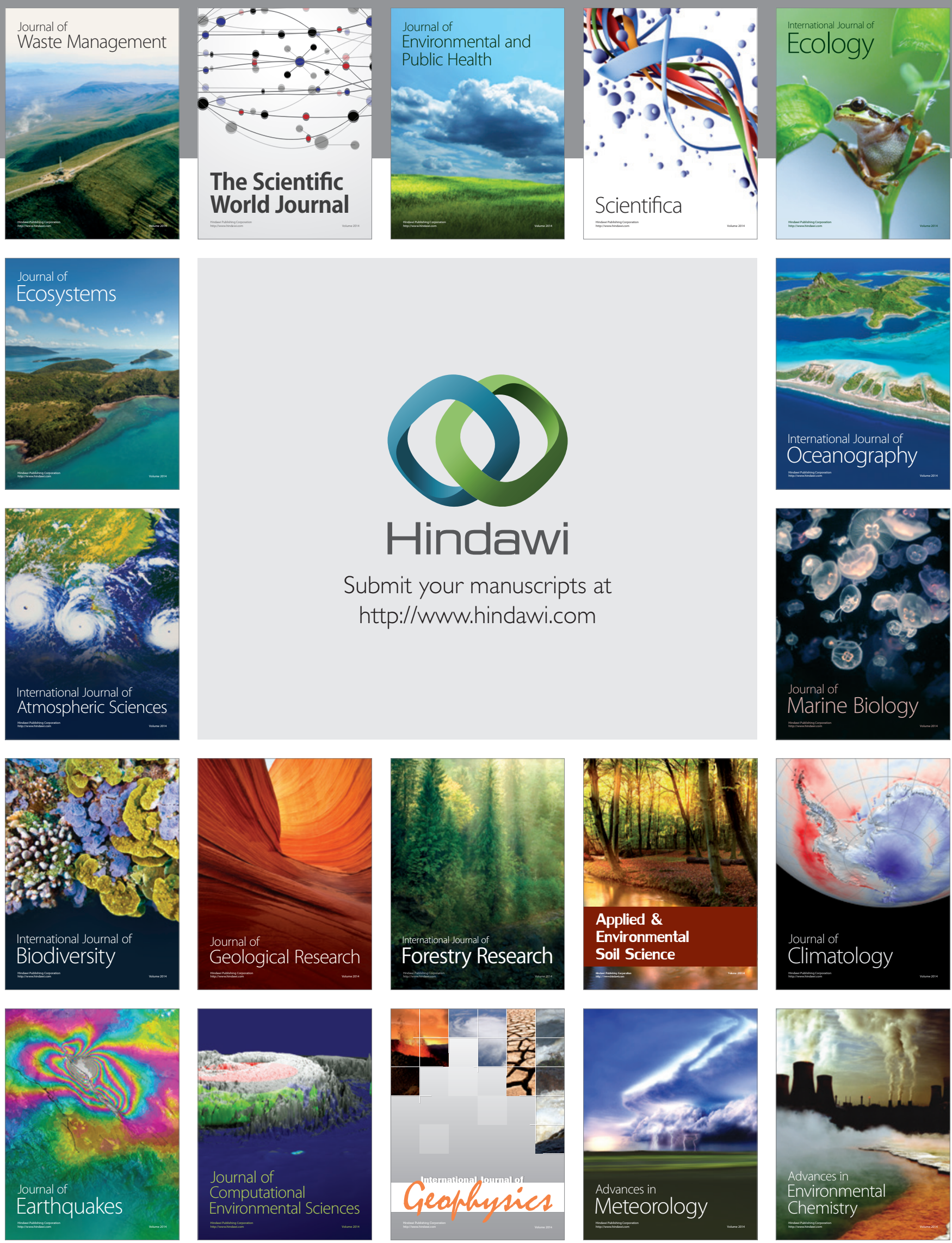